\title{
PENGETAHUAN REMAJA PUTRI TENTANG BAHAYA KEHAMILAN USIA MUDA DI SMA NEGERI 1 BAREGBEG KABUPATEN CIAMIS
}

\author{
Yudita Ingga Hindiarti ${ }^{1}$, Nabila Fauzia Rachmah ${ }^{2}$ \\ Program Studi DIII Kebidanan, Fakultas Ilmu Kesehatan, Universitas Galuh \\ Yuditaingga87@gmail.com, nabilaaaafr@gmail.com \\ (Diterima 25-11-2019; disetujui 18-11-2019; dipublish 26-11-2019)
}

\begin{abstract}
Abstrak
Masa remaja merupakan masa dimana terjadinya pertumbuhan dan perkembangan yang pesat. Masalah Kesehatan Reproduksi yang terjadi pada remaja selain berdampak secara fisik, mental, emosi juga berdampak secara ekonomi dan kesejahteraan sosial dalam jangka panjang. Munculnya dorongan seksual pada remaja menjadikannnya rawan terhadap penyakit dan masalah kesehatan reproduksi seperti hubungan seks pranikah yang berakibat terjadinya kehamilan usia muda. Tujuan penelitian adalah untuk mengetahui gambaran pengetahuan remaja putri tentang bahaya kehamilan Usia Muda di SMA Negeri 1 Baregbeg Kabupaten Ciamis Tahun 2019. Metode penelitian ini menggunakan metode penelitian deskriptif jumlah populasi dalam penelitian ini adalah 168 orang. dengan sampel sebanyak 118 orang. Hasil Penelitian pengetahuan remaja putri tentang bahaya kehamilan usia muda di SMA Negeri 1 Baregbeg didapatkan hasil $62(52,5 \%)$ remaja putri berpengetahuan kurang, 40 (33,9\%) remaja putri berpengatahuan cukup dan $16(13,6 \%)$ remaja putri berpengetahuan baik. Diharapkan orang tua, tenaga pendidik, dapat bekerjasama dengan petugas kesehatan dan instansi terkait seperti bidan atau Dinas Pengendalian Penduduk, Keluarga Berncana, Pemberdayaan Perempuan dan Perlindungan Anak (DPPKBP3A) dengan mengenalkan dan memberikan informasi mengenai kesehatan reproduksi pada remaja sejak dini.

Kata Kunci : kehamilan usia muda, kesehatan reproduksi, pengetahuan, remaja
\end{abstract}

\begin{abstract}
Background of the study, puberty is a stage which the high development growth happen. Reproductive case happens to teenager not only physical body, mentality, emotional but also economic and prosperity in long period. Sexuality of teenager is at risk of disease and reproductive health problem such as per-married intimacy that cause early stage of pregnancy. The study aimed at observing the teenagers' knowledge of early stage pregnancy risk at Senior High School 1 Baregbeg, Ciamis Regency in 2019. This study employed descriptive method which the population were 168 students and the samples were 118 students. The result of the study showed that teenagers' knowledge of early stage pregnancy risk at Senior High School 1 Baregbeg, there were 62 (52.5\%) uneducated teenagers, 40 (33.9\%) fair educated and 16 (13.6\%) well-educated teenagers. Conclusion and suggestion, it is expected that parents and educational staff could be collaborated with medical assistant and institutional association such midwife or demography department, family planning and birth control, women empowerment and child protection commission in introducing and counceling information about reproductive health of teenager in early stage.
\end{abstract}

Keyword: teenager, knowledge, reproductive health, early stage pregnancy

\section{PENDAHULUAN}

World Health Organization (WHO)

mengatakan remaja merupakan penduduk yang memiliki batasan usia antara 10-19 tahun.
Peraturan Menteri Kesehatan RI Nomor 25 tahun 2014 mengatakan remaja ialah penduduk dengan batasan usia antara 10-18 tahun. ${ }^{1}$ Munculnya dorongan seksual yang terjadi pada 
remaja menjadikannya rawan terhadap penyakit dan masalah kesehatan reproduksi seperti hubungan seks pranikah yang berakibat terjadinya kehamilan usia muda. ${ }^{2}$

Kehamilan usia muda adalah kehamilan yang terjadi pada seorang wanita dengan usia kurang dari 20 tahun. Padahal kehamilan pada usia tersebut memungkinkan terjadinya risiko-risiko pada wanita. Kehamilan yang terjadi pada wanita usia muda tersebut memberikan risiko komplikasi yang sangat besar pada ibu dan bayi yang dikandungnya seperti, terjadinya anemia, eklampsia, terjadinya abortus, partus prematurus, meningkatnya kematian perinatal, perdarahan dan tindakan operatis obstetrik. ${ }^{3}$

Survei Demografi dan Kesehatan Indonesia (SDKI) yang dilakukan pada tahun 2012 menyatakan bahwa angka kematian neonatal, bayi dan balita pada ibu yang berusia kurang dari 20 tahun memiliki kontribusi yang lebih tinggi dibandingkan dengan ibu yang berusia 20-30 tahun. ${ }^{4}$

Dinas Kesehatan Kabupaten Ciamis menyatakan bahwa prevalensi kematian ibu hamil dibawah usia 20 tahun di Kabupaten Ciamis tercatat sebanyak 83 kasus. Jumlah tersebut terbagi dalam beberapa penyebab kematian ibu diantaranya, perdarahan 32,8\%, abortus $21,8 \%$, preeklampsia $28 \%$, plasenta previa $11,4 \%$, dan infeksi $6 \%$. Komplikasi ini terjadi karena belum sempurnanya organ reproduksi dan belum adanya kesiapan wanita pada usia kurang dari 20 tahun untuk hamil, sehingga menyebabkan komplikasi yang dapat menimbulkan kematian pada ibu. ${ }^{5}$

Kehamilan usia muda yang terjadi sepanjang tahun 2018 sendiri banyak terjadi pada kelompok usia 17-18 tahun atau tingkat usia pendidikan Sekolah Menengah Atas (SMA). Fenomena yang terjadi tersebut membuktikan bahwa pada masa remaja minatnya pada seksual semakin meningkat. ${ }^{6}$

Pusat Informasi dan Konseling Remaja (PIK-Remaja) yang dibentuk oleh BKKBN melalui program Generasi Berecana (GenRe) tersebut merupakan suatu wadah kegiatan program Penyiapan Kehidupan Berkeluarga Bagi Remaja (PKBR) yang dikelola dari, oleh dan untuk remaja untuk remaja. Ruang lingkup PIK-Remaja tersebut meliputi aspek-aspek kegiatan pemberian informasi KRR (Kesehatan Reproduksi Remaja), Pendewasaan Usia Perkawinan, Keterampilan Hidup (Life Skills), pelayanan konseling, rujukan, pengembangan jaringan dan dukungan, serta kegiatan-kegiatan pendukung lainnya sesuai dengan ciri dan minat pada remaja. ${ }^{7}$

Analisis faktor yang dilakukan oleh Rosa (2012) mengenai kehamilan usia muda, ada dua faktor yang diketahui menyebabkan kehamilan usia muda. Dua faktor tersebut yaitu, faktor internal, yang disebabkan dorongan dalam diri mereka sendiri, sementara faktor pedidikan, ekonomi dan adat istiadat atau opini publik disebut sebagai faktor eksternal yang timbul karena adanya dorongan dari dalam luar diri wanita tersebut. ${ }^{8}$

Berdasarkan fakta serta mengingat tingginya angka kehamilan usia muda dan risiko serta bahaya yang akan ditimbulkan maka penulis tertarik untuk meneliti bagaimana pengetahuan siswi SMA tentang bahaya kehamilan usia muda. 


\section{METODE PENELITIAN}

Penelitian ini menggunakan metode deskriptif. Penelitian ini dilaksanakan pada bulan April tahun 2019 di SMA Negeri 1 Baregbeg Kabupaten Ciamis. Data yang didapatkan dengan membagikan kuesioner Pengambilan sampel dilakukan dengan teknik sampling yaitu simple random sampling, pada teknik ini setiap anggota memiliki keesempatan untuk diseleksi sebagai sampel dan didapatkan sebanyak 118 responden. ${ }^{9,10}$ Analisis data dilakukan secara univariat untuk mengetahui gambaran pengetahuan remaja putri tentang bahaya kehamilan usia muda.

\section{HASIL DAN PEMBAHASAN}

Berdasarkan penelitian yang dilakukan pada kelas X dan XI di SMA Negeri 1 Baregbeg Kabupaten Ciamis Tahun 2019 menggunakan kuesioner yang berjumlah 22 soal didapatkan hasil sebagai berikut :

\section{Tabel 1. Hasil Penelitian}

\begin{tabular}{lcc}
\hline Pengetahuan & F & $\%$ \\
\hline Baik & 16 & 13,6 \\
Cukup & 40 & 33,9 \\
Kurang & 62 & 52,5 \\
\hline \multicolumn{1}{c}{ Total } & 118 & 100 \\
\hline
\end{tabular}

Sumber : Analisis Data Primer (2019)

Berdasarkan hasil penelitian yang telah dilakukan menggunakan kuesioner dan diolah dalam sistem komputer Statistical Package for the Social Sciences (SPSS) maka didapatkan bahwa sebagian besar remaja putri memiliki pengetahuan kurang yaitu sebanyak $62(52,5 \%)$.
Berkaitan dengan penelitian ini maka remaja putri yang memiliki pengetahuan yang kurang tentang bahaya kehamilan usia muda akan timbul suatu pemahaman dan sikap yang negatif mengenai berbagai risiko atau bahaya dari kehamilan usia muda baik itu risiko bagi kehamilan, persalinan, maupun bagi bayi yang dilahirkannya sehingga dengan pemahaman dan sikap tersebut remaja putri cenderung akan melakukan pergaulan yang berkaitan dengan penyalahgunaan fungsi seksual yang dapat menyebabkan kehamilan pada usia muda. ${ }^{11}$

Pengetahuan responden yang kurang disebabkan karena kurangnya informasi yang diterima khususnya penyuluhan yang berkaitan dengan risiko kehamilan pada usia muda. Arsih (2009) dalam penelitiannya melaporkan bahwa para remaja tidak memiliki pengetahuan khusus dan komprehensif mengenai kehamilan usia muda serta dampaknya. Dan pengetahuan yang kurang disebabkan karena para remaja tidak terpapar informasi mengenai kehamilan usia muda berikut dampak yang akan ditimbulkannya. ${ }^{12}$

\section{Pengetahuan yang baik pada remaja} putri dapat menghindarkannya dari kehamilan usia muda. Infromasi yang tersedia melalui media massa, internet dan sumber lainnya dapat menjadi referensi yang baik bagi remaja putri, untuk mengetahui segala sesuatu tentang bahaya kehamilan usia muda. Informasi yang kurang jelas dan minim juga dapat menimbulkan rasa keingintahuan pada remaja itu sendiri. Rasa keingintahuan yang besar pada remaja tersebut dapat menjadi stimulus untuk remaja putri melakukan hubungan seksual yang akhirnya dapat memicu terjadinya kehamilan usia muda. ${ }^{13}$ 
Kurang berperan sertanya organisasi khususnya PIK-Remaja di lingkungan sekolah dalam pemberian informasi mengenai kesehatan reproduksi pada remaja, juga mengakibatkan ketidaktahuan remaja putri untuk mengetahui kesehatan reproduksi itu sendiri. Sehingga remaja putri tidak dapat memperoleh informasi yang akurat tentang kesehatan reproduksi khususnya mengenai bahaya kehamilan pada usia muda. PIKRemaja yang tidak begitu aktif tersebut, mungkin disebabkan karena kuranganya support dari pihak sekolah terhadap monitoring dan pengembangan program PIK-Remaja. Sehingga siswi di sekolah merasa kesehatan reproduksi khususnya bahaya kehamilan usia muda merupakan hal yang tabu untuk di diskusikan. ${ }^{14}$

\section{KESIMPULAN DAN SARAN}

Hasil penelitian terhadap responden mengenai pengetahuan tentang bahaya kehamilan usia muda yang di peroleh dari pengumpulan data melalui kuesioner yang disebarkan kepada responden dapat disimpulkan bahwa sebagian besar responden memiliki pengetahuan kurang tentang bahaya kehamilan usia muda sebanyak 62 orang $(52,5 \%)$.

Dengan masih adanya remaja yang memiliki pengetahuan kurang, diharapkan remaja lebih aktif dalam mencari informasi tentang bahaya kehamilan usia muda sehinga remaja itu sendiri dapat menghindari bahaya yang mungkin disebabkan karena kehamilan di usia muda.
Selain itu, tenaga pendidikan seperti guru Bimbingan dan Konseling (BK) dapat bekerjasama dengan petugas kesehatan atau instansi terkait seperti bidan atau DPPKBP3A dengan mengenalkan dan memberikan informasi mengenai kesehatan reproduksi secara dini, sehingga remaja putri mengetahui informasi yang akurat mengenai kesehatan reproduksi pada remaja, karena pengetahuan merupakan salah satu komponen kognitif dalam pembentukan sikap. Sehingga dengan pengetahuan yang baik dapat membentuk sikap yang positif dan memberikan perilaku yang baik bagi remaja.

\section{DAFTAR PUSTAKA}

\section{Carolli G, Ferguson J, Whyte $P$.} Preventing Early Pregnancy and Poor Reproductive Outcomes among adolescents in developing countries. WHO guideline. World Health Organization. 2011.

2. Aryani, R. Kesehatan Remaja : Problem dan solusinya. 2010.

3. Soetjiningsih, dr, $\mathbf{s p A}(\mathbf{K})$. Tumbuh Kembang Remaja dan Permasalahannya. Jakarta : Sagung Seto. 2011.

4. SDKI. Angka Kematian Neonatal di Indonesia. Available at : http://www.depkes.go.id

5. Dinkes Kab. Ciamis. Prevalensi Kematian Ibu hamil di bawah usia 20 tahun. available at : Profil Dinas Kesehatan Kabupaten Ciamis. 2018 
6. Hurlock, Elizabeth B. Psikologi Perkembangan. 5th rev. Jakarta : Erlangga. 2011.

7. BKKBN. Pusat Informasi dan Konseling Remaja. Available at : https://www.k4health.org

8. Rosa. Faktor mengenai kehamilan usia muda. Available at jurnal : faktorfaktor yang mempengaruhi kehamilan usia muda. 2012.

9. Sugiyono. Statistika Untuk Penelitian. Bandung : CV Alfabeta. 2015.

10. Notoatmodjo, S. Metodologi Penelitian Kesehatan. Jakarta : Rineka Cipta. 2012.

11. Annisa, Eka. Pengetahuan remaja putri tentang bahaya kehamilan usia muda. Available at Jurnal : Gambaran pengetahuan remaja putri tentang kehamilan remaja. 2018.

12. Arsih. Kurangnya pengetahuan remaja putri tentang bahaya kehamilan usia muda. Available at Jurnal : Gambaran Sikap Remaja Putri Tentang Bahaya Kehamilan Usia Muda. Bandung. 2009.

13. Narasiang, Wantania, Mewengkang. Pengetahuan yang baik pada remaja putri. Available at Jurnal : Gambaran Pengetahuan Sisri Tentang Kehamilan Remaja. 2015.

14. Hidayah, Indiarjo. Kurang berperan sertanya oganisasi PIK-Remaja. Available at Jurnal : http://journal.unnes.ac.id 